\title{
Determination of some minerals and heavy metal levels in Urfa cheese and cow's milk
}

\section{Serap KILIÇ ALTUN, Mehmet Emin AYDEMIIR}

Cite this article as:

Kılıç Altun, S., Aydemir, M.E. (2021). Determination of some minerals and heavy metal levels in Urfa cheese and cow's milk. Food and Health, 7(3), 185-193. https://doi.org/10.3153/FH21020

Harran University, Veterinary Faculty, Department of Food Hygiene and Technology, Şanlıurfa, Turkey

\section{ORCID IDs of the authors:} S.K.A. 0000-0002-4203-2508 M.E.A. 0000-0002-5849-1741

Submitted: 25.12 .2020

Revision requested: 13.01 .2021

Last revision received: 29.01 .2021

Accepted: 31.01 .2021

Published online: 13.05 .2021

Correspondence:

Mehmet Emin AYDEMIR

E-mail: aydemiremin23@harran.edu.tr

\section{ABSTRACT}

This research was carried out to determine the levels of some minerals and heavy metals in Urfa cheeses and cow's milk offered for sale in Şanlıurfa. Mineral and heavy metal levels were determined by analysing 18 Urfa cheese and 21 cow milk samples collected from retail outlets with ICP-MS. Mean mineral and heavy metal contents in Urfa cheese samples were; magnesium (Mg) $129.8 \pm 31.14 \mathrm{mg} / \mathrm{kg}$, calcium (Ca) $2712.66 \pm 1002.4 \mathrm{mg} / \mathrm{kg}$, potassium (K) $272.06 \pm 127.21 \mathrm{mg} / \mathrm{kg}$, titanium (Ti) $7.48 \pm 2.63 \mathrm{mg} / \mathrm{kg}$, zinc (Zn) $40.4 \pm 16.33 \mathrm{mg} / \mathrm{kg}$, selenium (Se) $10.6 \pm 3.51 \mathrm{mg} / \mathrm{kg}$. In cow milk samples, average selenium (Se) $0.22 \pm 0.04 \mathrm{mg} / \mathrm{kg}$, titanium (Ti) $0.07 \pm 0.009, \mathrm{mg} / \mathrm{kg}$, copper $(\mathrm{Cu}) 0.0068 \pm 0.01 \mathrm{mg} / \mathrm{kg}$ and chromium $(\mathrm{Cr})$ was detected at the level of $0.019 \pm 0.001$ $\mathrm{mg} / \mathrm{kg}$. Arsenic (As), cadmium (Cd), lead $(\mathrm{Pb})$ and thallium $(\mathrm{Tl})$ levels were below the detectable levels in Urfa cheese and cow's milk samples. As a result, it was concluded that the samples do not pose a significant danger to public health in terms of heavy metal pollution and can contribute significantly to nutrition with the mineral substances it contains.

Keywords: Cow milk, Urfa cheese, Mineral, Heavy metal, ICP-MS

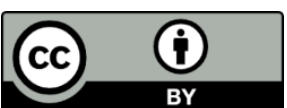

(c) 2021 The Author(s) 


\section{Introduction}

Milk is a nutrient secreted in the mammary glands of female mammals and produced to feed their offspring. Various foods obtained from milk are called "dairy products" (İstanbulluoğlu et al. 2016). Milk and dairy products contain important nutrients, which are essential for human life. Milk is highly preferred food because it has high biological values and rich with nutrients (Licata et al., 2004). Cheese is a dairy product produced by the coagulation of milk casein, produced in a variety of flavors and textures. For centuries, cheese is a dairy product that has an important place in the nutrition of all societies. In addition to being rich in high quality protein, fat and vitamins, it is easily digestible (Öksüztepe et al., 2013). Milk and cheese are rich in not only protein, fat and vitamins, but also macro elements such as sodium, calcium and phosporus. In addition to macro-elements milk and cheese also contains trace elements such as $\mathrm{Zn}, \mathrm{Fe}, \mathrm{Cu}$ and $\mathrm{Se}$ (Mendil, 2006; Altun and Paksoy, 2020). Mineral content of milk may vary depending on the genetic characteristics of the animal, the lactation period, environmental conditions, type of pasture and soil pollution (Özlü et al., 2012).

In our country, besides white cheese, tulum cheese, cheddar cheese and mihalic cheese, many local cheese varieties are also produced. These types of cheese are generally obtained by primitive techniques. Urfa cheese is also one of the local cheese. The production of Urfa cheese is mostly made in the Southeastern Anatolia Region and especially around Şanluurfa province. Urfa cheese is usually made from sheep and goat milk. Its production is mostly done in villages using traditional methods. Urfa cheese is a semi-hard cheese matured in salt water. By adding rennet to milk, it is allowed to coagulate in about 60 minutes at $30-32^{\circ} \mathrm{C}$. After coagulation step curd is subjected to dry salting for 12-24 hours and stored in salt water for 3-4 months. Some manufacturers boil the cheese in boiling whey for 3-5 minutes before salting. During its production, it is generally carried out using primitive tools and equipment without paying attention to hygienic rules (Atasoy et al., 2004).

Although milk and cheese have many benefits in nutrition, they can sometimes contain many environmental pollutants such as pesticides, detergents, drug residues, heavy metals, which may be dangerous for human health (Licata et al., 2004). Heavy metals contamination of milk and milk products can sometimes occur during the processing of milk into the product. Generally, heavy metal contamination is transmitted from environmental sources such as soil and water or feed consumed by the animal. In addition, metals in the composition of machinery and equipment used during milk storage and processing can dissolve into the product during milk- ing. The elements that can pass from machinery and equipment to milk and cheese are $\mathrm{Cu}, \mathrm{Zn}, \mathrm{Cd}, \mathrm{As}, \mathrm{Pb}$ (Bakırcıoğlu et al., 2011). Heavy metals tend to accumulate in the tissues of the human body, reaching toxic values over time, causing serious health problems. Heavy metals can be transmitted to the human body through digestion, respiration and skin. Heavy metals can cause acute, subacute and chronic intoxication symptoms depending on the frequency, duration and dose taken into the body. Some of these symptoms are liver necrosis, microcytic anemia, memory retardation, speech and voice disorders (Özturan and Atasever, 2018). Different methods have been used like flame atomic absorption spectrometry (FAAS), inductively coupled plasma-mass spectrometry (ICP-MS), induced plasma-optical emission spectrometry (ICP-OES), atomic absorption spectrometry (AAS), etc. to measure mineral levels in various milk and dairy products. (Özlü et al., 2012; Öksüztepe et al., 2013; Öztürk, 2009; Temurci and Güner, 2006; İşleyici et al., 2017; Kılıçel et al., 2004). The aim of this study is to determine the levels of some minerals and heavy metals in Urfa cheeses and cow's milk offered for sale in Şanlıurfa with the ICP-MS device.

\section{Materials and Methods}

\section{Sampling}

Within the scope of the study, 18 Urfa cheese samples made from sheep's milk and 21 cow milk samples were taken from local producers in the central district of Şanluurfa province for sale. Cheese samples were provided as $250 \mathrm{~g}$ and milk samples as $25 \mathrm{~mL}$, they were brought to the laboratory immediately in compliance with the cold chain conditions and they were kept at $-19^{\circ} \mathrm{C}$ until the analysis process.

\section{Preparation of the Samples}

After the cheese and milk samples were homogenized, 1 gram of each sample was weighed and taken into the sample containers of the microwave device. $4 \mathrm{~mL}$ of $65 \%(\mathrm{v} / \mathrm{v})$ nitric acid $\left(\mathrm{HNO}_{3}\right)$ and $2 \mathrm{~mL}$ of $30 \%$ (v/v) hydrogen peroxide $\left(\mathrm{H}_{2} \mathrm{O}_{2}\right)$ were added with a pipette and placed in the microwave device. Cheese and milk samples were digested in microwave oven with a program whose temperature and duration were predetermined (Table 1). After microwave digestion cheese and milk samples were taken into sterile tubes after cooling, and diluted with ultrapure water (Paksoy at al. 2018). 


\section{Analysis of the Samples}

Mineral and heavy metal analysis of cheese and milk samples were performed with the Agilent brand 7500ce series ICPMS (Tokyo, Japan) device in the Mersin University Advanced Technology Education, Research and Application Center laboratory.

\section{Quality Control}

Limit of quantification (LOQ) and limit of detection (LOD) of each element was calculated as 10 times and the recovery of 12 elements ( $\mathrm{Mg}, \mathrm{K}, \mathrm{Ca}, \mathrm{Ti}, \mathrm{Zn}, \mathrm{As}, \mathrm{Cr}, \mathrm{Se}, \mathrm{Cu}, \mathrm{Cd}, \mathrm{Tl}$, $\mathrm{Pb}$ ) in Urfa cheese and cow milk samples are shown in Table 2.

\section{Statistical Evaluations}

All data were analyzed statistically using SPSS 22.0 (SPSS Inc., Chicago, IL, USA) software.

Table 1. Burning process steps in microwave device

\begin{tabular}{ccc}
\hline Stage & Temperature $\left({ }^{\circ} \mathbf{C}\right)$ & Time $(\min )$ \\
\hline 1 & 90 & 8 \\
\hline 2 & 170 & 10 \\
\hline 3 & 210 & 25 \\
\hline
\end{tabular}

Table 2. Quality control.

\begin{tabular}{lll}
\hline Element & LOQ & LOD \\
\hline $\mathbf{M g}\left(\mathrm{mg} \mathrm{L}^{-1}\right)$ & 48.58 & 4.6 \\
$\mathbf{K}\left(\mathrm{mg} \mathrm{L}^{-1}\right)$ & 1013 & 200 \\
$\mathbf{C a}\left(\mathrm{mg} \mathrm{L}^{-1}\right)$ & 578 & 22 \\
$\mathbf{T i}\left(\mathrm{mg} \mathrm{L}^{-1}\right)$ & 6.8 & 0.1 \\
$\mathbf{Z n}\left(\mathrm{mg} \mathrm{L}^{-1}\right)$ & 1.81 & 0.2 \\
$\mathbf{A s}\left(\mathrm{mg} \mathrm{L}^{-1}\right)$ & 0.18 & 0.01 \\
$\mathbf{C r}\left(\mathrm{mg} \mathrm{L}^{-1}\right)$ & 0.1 & 0.01 \\
$\mathbf{S e}\left(\mathrm{mg} \mathrm{L}^{-1}\right)$ & 0.24 & 0.1 \\
$\mathbf{C u}\left(\mathrm{mg} \mathrm{L}^{-1}\right)$ & 0.06 & 0.01 \\
$\mathbf{C d}\left(\mathrm{mg} \mathrm{L}^{-1}\right)$ & 0.11 & 0.01 \\
$\mathbf{T l}\left(\mathrm{mg} \mathrm{L}^{-1}\right)$ & 0.2 & 0.02 \\
$\mathbf{P b}\left(\mathrm{mg} \mathrm{L}^{-1}\right)$ & 0.16 & 0.01 \\
\hline
\end{tabular}

LOD: Limit of detection; LOQ: Limit of quantification

\section{Results and Discussion}

Within the scope of the study, the average, standard deviations, the lowest and highest levels of mineral substances and heavy metal amounts of cheese samples are shown in Table 3 and Figure 1. The average, standard deviations, the lowest and highest values of the milk samples are shown in Table 4 and Figure 1.

Trace element and heavy metal contents of milk and dairy products may vary depending on the lactation stage, the nutritional status of the animal, environmental and genetic factors, or possible contamination during production (Özturan and Atasever, 2018).

Table 3. Mineral levels of Urfa cheese samples (mg/kg).

\begin{tabular}{cccc}
\hline Element & Min & Max & Mean $(\mathbf{x} \pm \mathbf{S x})$ \\
\hline $\mathbf{M g}$ & 92.9 & 227.7 & $129.8 \pm 31.14$ \\
$\mathbf{K}$ & 98.9 & 555.1 & $272.06 \pm 127.21$ \\
$\mathbf{C a}$ & 1828 & 6025 & $2712.66 \pm 1002.4$ \\
$\mathbf{T i}$ & 5.2 & 16.2 & $7.48 \pm 2.63$ \\
$\mathbf{Z n}$ & 23.9 & 75.4 & $40.4 \pm 16.33$ \\
$\mathbf{A s}$ & $<$ LOD & $<$ LOD & $<$ LOD \\
$\mathbf{S e}$ & 1.8 & 14.7 & $10.6 \pm 3.51$ \\
$\mathbf{C d}$ & $<$ LOD & $<$ LOD & $<$ LOD \\
$\mathbf{T l}$ & $<$ LOD & $<$ LOD & $<$ LOD \\
$\mathbf{P b}$ & $<$ LOD & $<$ LOD & $<$ LOD \\
\hline
\end{tabular}

n:18, x: Arithmetic Mean, Sx: Standard Deviation, LOD: Limit of detection 
Table 4. Mineral levels of cow's milk samples (mg/kg).

\begin{tabular}{cccc}
\hline Element & Min & Max & Mean $(\mathbf{x} \pm \mathbf{S x})$ \\
\hline $\mathbf{S e}$ & 0.13 & 0.31 & $0.22 \pm 0.04$ \\
$\mathbf{T i}$ & 0.05 & 0.08 & $0.07 \pm 0.009$ \\
$\mathbf{C r}$ & $<$ LOD & 0.01 & $0.019 \pm 0.001$ \\
$\mathbf{C u}$ & $<$ LOD & 0.04 & $0.0068 \pm 0.01$ \\
$\mathbf{A s}$ & $<$ LOD & $<$ LOD & $<$ LOD \\
$\mathbf{C d}$ & LOD & $<$ LOD & $<$ LOD \\
$\mathbf{T l}$ & $<$ LOD & $<$ LOD & $<$ LOD \\
$\mathbf{P b}$ & $<$ LOD & $<$ LOD & $<$ LOD \\
\hline
\end{tabular}

n:21, x: Arithmetic Mean, Sx: Standard Deviation, LOD: Limit of detection

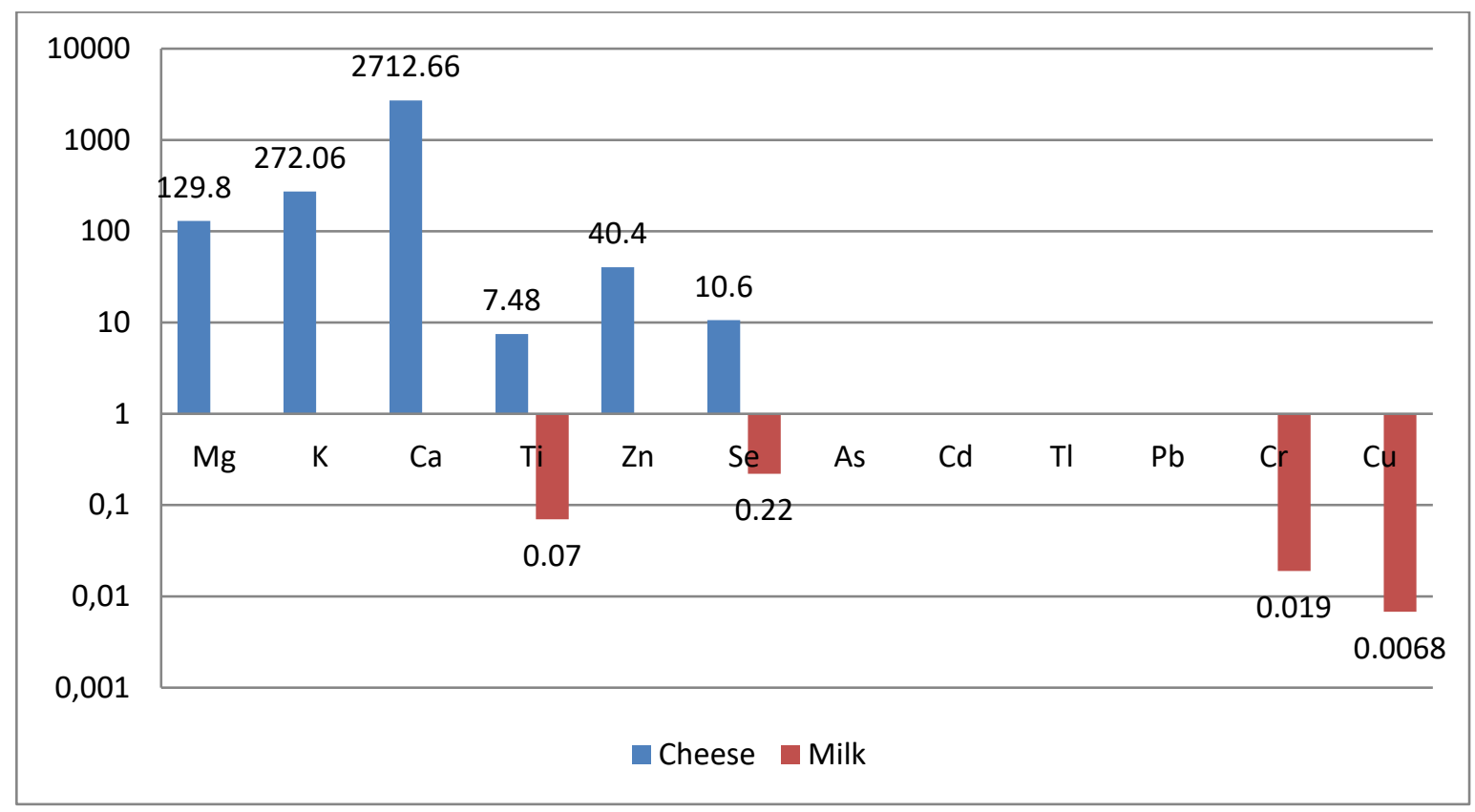

Figure 1. Mineral levels $(\mathrm{mg} / \mathrm{kg})$ of Urfa cheese and cow's milk samples.

$\mathrm{Ca}$ is responsible for many functions in the body such as heart rhythm, blood coagulation, hormone secretion, muscle contraction, enzyme activation in the body, and is also found in the structure of bones. Ca makes up $1.5-2 \%$ of an adult's mass. Milk and dairy products are foods rich in $\mathrm{Ca}$ which is one of the most important mineral substances in cheese, and its amount varies according to the type of cheese (Altun et al., 2016). In our study, the average $\mathrm{Ca}$ amount in Urfa cheeses is $2712.66 \pm 1002.4 \mathrm{mg} / \mathrm{kg}$. The amount of $\mathrm{Ca}$ in Urfa cheese is lower than the amount of Ca reported by many researchers in cheeses (Demirci, 1988; Arslan et al. 1996; Mendil, 2006; Öksüztepe et al., 2013; İşleyici et al., 2017; Altun et al., 2016; Çetinkaya et al., 2016), but higher than the values found by some researchers (Ayar et al., 2006; Kirdar et al., 2015; Arslaner and Salık, 2020). According to the results of this study, it was seen that the Ca content of Urfa cheese can be a good source in human nutrition.

$\mathrm{Mg}$ has many functions involved in more than 300 reactions in the body. Milk and dairy products are a good source of $\mathrm{Mg}$. There is approximately $100 \mathrm{mg}$ of $\mathrm{Mg}$ in a liter of milk (Haug et al., 2007). The amount of $\mathrm{Mg}$ in milk varies depending on the lactation period, the animal's feeding and the treatment applied to the milk. In our study, the average amount of $\mathrm{Mg}$ in Urfa cheeses was $129.8 \pm 31.14 \mathrm{mg} / \mathrm{kg}$. The amount of $\mathrm{Mg}$ in Urfa cheese was lower than the amount of Mg reported by 
many researchers (Öksüztepe et al., 2013; İşleyici et al., 2017; Kılıçel et al., 2004; Altun et al., 2016; Çetinkaya et al., 2016; Arslaner and Sal1k, 2020; Özbek and Akman, 2016). It was higher than the values found by some researchers (Mendil, 2006; Ayar et al., 2006; Kirdar et al., 2015). The difference in the amount of $\mathrm{Mg}$ is thought to be due to the milk used in the production of the cheese or the techniques used in the production and the environmental conditions of the region.

$\mathrm{K}$ has many functions such as osmotic pressure, electrolyte balance, acid-base balance, nerve stimulation, contraction of the heart and other muscles, protein synthesis, and the conversion of glucose into glycogen (Özturan and Atasever, 2018). Milk and dairy products also contain some K. The amount of $\mathrm{K}$ also changes depending on the lactation period, the ration of the animal and the process applied to the milk. In our study, the average $\mathrm{K}$ level in Urfa cheese was 272.06 $\pm 127.21 \mathrm{mg} / \mathrm{kg}$. The amount of $\mathrm{K}$ in Urfa cheese was lower than the amount of $\mathrm{K}$ reported by many researchers in cheeses (Öksüztepe et al., 2013; İşleyici et al., 2017; Demirci, 1988; Arslan et al. 1996; Çetinkaya et al., 2016; Kirdar et al., 2015; Arslaner and Salık, 2020). The results close to the values found by some researchers (Mendil, 2006; Altun et al., 2016, Özbek and Akman, 2016). Park (2000) stated that significant amounts of $\mathrm{K}$ in cheese are lost during cheese production. The reason for the lower amount of $\mathrm{K}$ in Urfa cheese compared to other cheeses suggests that it may be due to production.

Zn plays a role in many physiological processes such as nucleic acid and protein synthesis, cellular replication, insulin secretion, sexual maturation, and strengthening of the immune system. High concentrations of $\mathrm{Zn}$ cause nausea and vomiting in children, anemia and cholesterol problems in adults (Özturan and Atasever, 2018). In our study, the average $\mathrm{Zn}$ level in Urfa cheeses is $40.4 \pm 16.33 \mathrm{mg} / \mathrm{kg}$. The amount of $\mathrm{Zn}$ in Urfa cheese was higher than the amount of $\mathrm{Zn}$ found by many researchers in cheeses (Mendil, 2006; Öksüztepe et al., 2013; Altun et al., 2016; İşleyici et al., 2017; Çetinkaya et al., 2016; Kirdar et al. , 2015; Yalçın and Tekinşen, 2010). It was lower than the values found by some researchers (Demirci, 1988; Kirdar et al., 2015). The fact that the $\mathrm{Zn}$ content of Urfa cheese was higher than the $\mathrm{Zn}$ content reported in other cheeses suggests that it may be due to $\mathrm{Zn}$ contamination caused by the materials used in the production stages of Urfa cheese.

Se plays an important role in immunity, antioxidant system, DNA synthesis and DNA repair. The recommended daily intake of Se is $55 \mu \mathrm{g}$. It is an important source of Se in milk and dairy products (Haug et al., 2007). In our study, the average Se amounts in Urfa cheese and cow milk are $10.6 \pm 3.51$ $\mathrm{mg} / \mathrm{kg}, 0.22 \pm 0.04 \mathrm{mg} / \mathrm{kg}$, respectively. Ayar et al. (2007) reported that they found the highest Se value in various milk and dairy products with $0.434 \mathrm{mg} / \mathrm{kg}$ in tulum cheese and then in butter with $0.315 \mathrm{mg} / \mathrm{kg}$. In a study conducted on dairy products in Italy, the Se amount of Groviera cheese was found to be $1.10 \mathrm{mg} / \mathrm{kg}$ (Garcia et al., 2006). It has been reported that the Se amount in Bayburt civil cheese was between 0.00-723.57 $\mu \mathrm{g} / \mathrm{kg}$ (Arslaner and Salık, 2020). In a study, it was stated that Se is kept in the casein network so it was determined in higher amounts in semi-hard cheeses than in milk (Garcia et al., 2006). Since Urfa cheese is a semi-hard cheese, the Se content was high.

$\mathrm{Ti}$ is a naturally occurring light mineral on earth. Taking Ti into the body in large quantities is not toxic (Şanal and Güler, 2010). Titanium dioxide has recently been used in nanotechnology applications in foods. It is also used as a food additive to increase the color brightness in milk products (Berik, 2018). In our study, the average Ti amounts in Urfa cheese and cow milk are $7.48 \pm 2.63 \mathrm{mg} / \mathrm{kg}, 0.07 \pm 0.009 \mathrm{mg} / \mathrm{kg}$, respectively. Studies on Ti levels in milk and dairy products are limited. Şanal and Güler (2010) reported in their study that they found the amount of $\mathrm{Ti}$ in cow milk at the level of $0.31 \pm 0.23 \mathrm{mg} / \mathrm{kg}$ in the province of Hatay. Dobrzanski et al. (2005) reported that Ti content in raw milk of cows in lower Silesia and upper Silesia (USA) was $104.42 \pm 24.70,54.48$ $\pm 29.40 \mu \mathrm{g} / \mathrm{L}$, respectively.

$\mathrm{Cu}$ is required as a necessary trace element for adequate growth, cardiovascular system, lungs, neuronendocrine function and iron metabolism. $\mathrm{Cu}$ is an essential trace element but have dangerous effects on the human body in high concentrations. As a result of contamination, $\mathrm{Cu}$ can reach high levels in milk and dairy products (Özturan and Atasever, 2018). JECFA (Joint FAO/WHO Expert Comitee on Food Additives) has determined the maximum daily allowable dose for $\mathrm{Cu}$ as $0.5 \mathrm{mg} / \mathrm{kg}$. In the Turkish Food Codex Regulation on Contaminants in Foodstuffs, the maximum acceptable value for $\mathrm{Cu}$ was not specified (Anonymous, 2011). According to the Food Codex Commission within the Food-Agriculture Organization (FAO) and World Health Organization (WHO), the maximum amount of $\mathrm{Cu}$ that can be found in foods is 0.1$5.0 \mathrm{mg} / \mathrm{kg}(\mathrm{FAO} / \mathrm{WHO}, 2012)$. In our study, the average $\mathrm{Cu}$ amount in cow milk was determined as $0.0068 \pm 0.01 \mathrm{mg} / \mathrm{kg}$. The reported average amount of $\mathrm{Cu}$ in milk samples in Licata et al.'study (2004) was $1.98 \mu \mathrm{g} / \mathrm{kg}$, Şimsek et al.'s (2000) study was $0.39-0.96 \mathrm{mg} / \mathrm{kg}$, Temurci and Güner's (2006) study was 4,300 mg/L, Yüzbaş1 et al.'s (2009) study was 1.7 $\mathrm{mg} / \mathrm{kg}$ and Beykaya et al.'s (2019) study was $33.69 \mu \mathrm{g} / \mathrm{kg}$. Inci et al. (2017) reported that the $\mathrm{Cu}$ content was below the detectable limit. Our results were parallel with the other studies. 
Because heavy metals cause acute and chronic health problems, national and international food organizations have introduced regulations to prevent contamination. However, in the communiqué on determining the maximum levels of certain contaminants in foodstuffs of the Turkish Food Codex, no limit has been determined for milk and dairy products. A limit was set for $\mathrm{Pb}$ as $0.020 \mathrm{mg} / \mathrm{kg}$.

Be a metal that can be found everywhere in nature, $\mathrm{Cr}$ affects carbohydrate and protein metabolism by providing insulin movement in the body. The average daily intake of $\mathrm{Cr}$ by a person is between 30 and $200 \mu \mathrm{g}$ (Beykaya et al. 2019). Milk and dairy products contain low amounts of $\mathrm{Cr}$ (Kahvecioğlu et al., 2009). In the Turkish Food Codex Contaminants Regulation, there is no limit for the amount of $\mathrm{Cr}$ in foodstuffs (Anonymous, 2011). In our study, the average $\mathrm{Cr}$ amount in cow milk is $0.019 \pm 0.001 \mathrm{mg} / \mathrm{kg}$. Beykaya et al. (2019), Licata et al. (2004), Temurci and Güner (2006) reported an average amount of Cr $31.81 \mu \mathrm{g} / \mathrm{kg}, 2.03 \mu \mathrm{g} / \mathrm{L}, 1.016 \mathrm{mg} / \mathrm{L}$, respectively. The amount of Crin this study in cow's milk is very low and it was lower than the other studies.

$\mathrm{Cd}$ is considered as the most important food contaminant and it is important because it has negative effects on human health (Özturan and Atasever, 2018). In the Turkish Food Codex Contaminants Regulation, no limit is specified for $\mathrm{Cd}$ in milk and its products, but it has been reported that it should be between $0.05-1.00 \mathrm{mg} / \mathrm{kg}$ for some other foods (Anonymous, 2011). In the study we conducted, the amount of Cd was found below the detection limits $(<\mathrm{LOD})$ in milk and cheese. Boudebbouz et al. (2020) found the Cd levels in milk samples from thirty-six regions around the world are above the standard limit of $0.0026 \mu \mathrm{g} / \mathrm{g}$, that Cd levels in milk samples in 18 regions are below the standard limit $(0.0026 \mu \mathrm{g} / \mathrm{g})$ and in five regions $\mathrm{Cd}$ It has been reported that their levels are below the detectable limit. In many studies conducted to determine the level of heavy metals in cow's milk in our country, Cd was detected, even in low amounts (Yüzbaş1 et al., 2009; Beykaya et al., 2019; Ay and Karayünlü, 2008). İnci et al. (2017), in line with our study, reported that the amount of $\mathrm{Cd}$ in raw milk collected in Aydın was below the detectable limit. In many studies related to heavy metal levels in cheeses, $\mathrm{Cd}$ was found even at low levels (İşleyici et al., 2017; Çetinkaya et al., 2016; Yalçın and Tekinşen, 2010; Ayar et al., 2009; Eroğlu, 2019). Öksüztepe et al. (2013) found the amount of $\mathrm{Cd}$ in cheese samples below the detectable limit, in parallel with our study.

The presence of $\mathrm{Pb}$ in milk and dairy products may from the environmental sources (atmosphere, vehicle exhausts, urban waste, etc.). $\mathrm{Pb}$ is a kind of neurotoxin and causes abnormal brain and nervous system functions (Kahvecioğlu et al., 2009). $\mathrm{Pb}$ is toxic and has negative effects on human health.
The Codex Alimentarius Commission (FAO/WHO, 2012) determined the $\mathrm{Pb}$ amount at the level of $0.02 \mathrm{mg} / \mathrm{kg}$ for milk and dairy products. In the Turkish Food Codex Contaminants Regulation, the highest acceptable $\mathrm{Pb}$ value was determined as $0.020 \mathrm{mg} / \mathrm{kg}$ for milk and its products (Anonymous, 2011). Many studies have reported that $\mathrm{Pb}$ levels in milk samples are below the specified limits (Licata et al., 2004; Ay and Karayünlü, 2008; Beykaya et al., 2019; İnci et al., 2017). In this study the amount of $\mathrm{Pb}$ was found below the detection limits $(<\mathrm{LOD})$ in milk and cheese. In many studies on heavy metal levels in cheeses, $\mathrm{Pb}$ was found even at low levels (Mendil, 2006; Yalçın and Tekinşen, 2010; İşleyici et al., 2017; Çetinkaya et al., 2016; Ayar et al., 2009; Eroğlu , 2019). Öksüztepe et al. (2013) found the Pb content in cheese samples was below the detectable limit, in parallel with our study.

As being common in nature and increasing environmental exposure today caused the increase of high As content in some products. As is also contaminated to milk and dairy products from the environment (İstanbulluoğlu et al., 2016). In our study, the amount of As was found below the detection limits $(<$ LOD) in milk and cheese samples. In line with our results, Öksüztepe et al. (2013) in Tulum cheese, Serencam et al. (2018) in çivil cheeses did not detect As. Some researchers have identified As in milk and dairy products (İstanbulluoğlu et al.2016; Ayar et al., 2007).

TI joins the food chain by passing from soil to plants. TI is one of the most toxic metals to metabolism. $\mathrm{Cd}, \mathrm{Pb}, \mathrm{Cu}, \mathrm{Zn}$ are both toxic. TI affects many systems (gastrointestinal, cardiovascular and urinary) as it accumulates in the body. General symptoms caused by TI are fatigue, loss of appetite, foot pain, headache, depression and hair loss (Leonard et al., 1997). The amount of TI is high in the milk and meat of animals fed in regions with high TI in the soil (Şanal and Güler, 2010). In our study, the amount of TI was found below the detection limits $(<$ LOD) in milk and cheese. Studies on the amount of TI in animal foods are limited. Şanal and Güler (2010) reported in their study that they found the $\mathrm{Tl}$ amount in cow's milk at the level of $7.01 \pm 0.80 \mathrm{mg} / \mathrm{kg}$ in the province of Hatay. Dobrzanski et al. (2005) reported that the TI amount in the raw milk of cows in the lower Silesia and upper Silesia regions in America was $(0.73 \pm 0.44,0.84 \pm 0.81) \mu \mathrm{g} / 1$, respectively.

\section{Conclusion}

The mineral substance levels of the samples showed that Urfa cheese and cow's milk are important foodstuffs for human nutrition. In addition, it was observed that the heavy metal levels of Urfa cheese and cow's milk did not exceed the limits specified in national and international standards. The very low 
heavy metal levels of Urfa cheese and cow milk are thought to be due to the very low level of heavy metal pollution in the region. As a result, it was concluded that Urfa cheese and cow milk in Urfa province can contribute significantly to nutrition due to the minerals in its composition, and it does not pose a significant danger to public health in terms of heavy metal pollution. However, industrialisation continuously increasing may be pose a risk in terms of heavy metals contamination on milk and milk products therefore this risks should be checked proper interval time.

\section{Compliance with Ethical Standard}

Conflict of interests: The authors declare that for this article they have no actual, potential or perceived the conflict of interests.

Ethics committee approval: Author declare that this study does not include any experiments with human or animal subjects.

Funding disclosure: -

Acknowledgments: -

Disclosure: -

\section{References}

Altun, İ., Köse, Şenol, Ş. (2016). Geleneksel kelle peynirinin bazı özelliklerinin belirlenmesi. Yüzüncü Yll Üniversitesi Tarım Bilimleri Dergisi, 26(4), 642-647.

https://doi.org/10.29133/yyutbd.282843

Altun, S.K., Paksoy, N. (2020). Şanlıurfa'da üretilen Urfa peynirlerinde nikel düzeyleri. Harran Üniversitesi Veteriner Fakültesi Dergisi, 9(1), 49-52.

https://doi.org/10.31196/huvfd.699304

Anonymous, (2011). Türk Gida Kodeksi Bulaşanlar Yönetmeliği. 29.09.2011 Tarihli ve 28157 Sayılı Resmi Gazete, http://www.resmigazete.gov.tr/es-

kile/2011/12/20111229M3- 8.htm

Arslan, A., Güven, A., Gönülalan, Z., Özmen, H. (1996). Şavak tulum peynirinin mineral madde düzeyi. Firat Üniversitesi Sağlık Bilimleri Dergisi, 10, 265-268.

Arslaner, A., Salık, M.A. (2020). Bayburt civil peynirinin bazı kimyasal, biyokimyasal ve mikrobiyolojik özellikleri ile mineral ve ağır metal içerikleri. Glda, 45(3), 433-447.

https://doi.org/10.15237/gida.GD19159

Atasoy, A.F., Akin M.S. (2004). Sanliurfa ilinde satisa sunulan Urfa peynirlerinin bazi kimyasal ozellikleri ve proteoliz duzeylerinin belirlenmesi uzerine bir arastirma, Harran Universitesi Ziraat Fakultesi Dergisi 8, 9-15.

Ayar, A., Akın, N., Sert, D. (2006). Bazı peynir çeşitlerinin mineral kompozisyonu ve beslenme yönünden önemi. Türkiye 9. Gida Kongresi, 319-322.

Ayar, A., Sert, D., Akın, N. (2007). Konya'da tüketime sunulan süt ve ürünlerinin ağır metal içeriklerinin belirlenmesi. Selcuk Journal of Agriculture and Food Sciences, 21(41), 58-64.

Ay, Ü., Karayünlü, S. (2008). Modification in direct analysis method: metal levels in raw milk at the region of Izmit by graphite furnace atomic absorption spectrophotometer. International Journal of Food Science and Technology, 43, 326329.

https://doi.org/10.1111/j.1365-2621.2006.01441.x

Ayar, A., Sert, D., Akın, N. (2009). The trace metal levels in milk and dairy products consumed in middle Anatolia Turkey. Environmental monitoring and assessment, 152(1-4), 112. https://doi.org/10.1007/s10661-008-0291-9

Bakırcıoğlu, D., Bakırcığlu K.Y., Uçar, G. (2011). Determination of some trace metal levels in cheese samples packaged in plastic and tin containers by ICP-OES after dry, wet and microwave digestion. Food Chemical Toxicology, 49, 202- 207.

https://doi.org/10.1016/j.fct.2010.10.017

Berik, N. (2018). Titanyum dioksit ve nano titanyum dioksit kullanımının su ürünlerine olası zararları. Çanakkale Onsekiz Mart University Journal of Marine Sciences and Fisheries, 1(2), 59-65.

Boudebbouz, A., Boudalia, S., Bousbia, A., Habila, S., Boussadia, M.I., Gueroui, Y. (2020). Heavy metals levels in raw cow milk and health risk assessment across the globe: A systematic review. Science of the Total Environment, 141830.

https://doi.org/10.1016/j.scitotenv.2020.141830

Beykaya, M., Yıldırım, Z., Özbey, A., Yıldırım, M. (2019). Determination of heavy metal content of milk collected by some dairy plants in Sivas. Turkish Journal of AgricultureFood Science and Technology, 7(1), 105-109. https://doi.org/10.24925/turjaf.v7i1.105-109.2164 
Çetinkaya, A., Akbaba, G.B., Özçakmak, S., Gülbaz, G. (2016). Trabzon'da tüketime sunulan cami boğazı peynirlerinin mineral madde içeriği ve ağır metal kontaminasyonu. Gida, 41(5), 317-322.

Demirci, M. (1988). Ülkemizin önemli peynir çeşitlerinin mineral madde düzeyi ve kalori değerleri. Gida, 13, 17-21.

Dobrzanski, Z., Kolacz, R., Górecka, H., Chojnacka, K., ve Bartkowiak, A. (2005). The content of microelements and trace elements in raw milk from cows in the Silesian region. Polish Journal of Environmental Studies, 14(5), 685.

Eroğlu, Y. (2019). Erzincan yöresinde üretilen tulum peynirlerinin benzoik asit, sorbik asit ve ağır metal içeriği yönünden incelenmesi. Erzincan Üniversitesi Fen Bilimleri Enstitüsü Dergisi, 12(3), 1295-1300.

https://doi.org/10.18185/erzifbed.656186

FAO/WHO (2012). Food and Agriculture Organization/World Health Organization. Joint FAO/WHO food standards program: Codex committee on contaminants in foods (Editorial amendments to the general standard for contaminants and toxins in food and feed), sixth session, Maastricht, Netherlands, (p. 26-30). March, 2012; ISBN: 978-92$5-105807-7$

Garcia, M.I.H., Puerto, P.P., Baquero, M.F., Rodriguez, E.R., Martin, J.D. ve Romero, C.D. (2006). Mineral and trace element concentrations of dairy products from goats' milk produced in tenerife (Canary Islands). International Dairy Journal, 16,182-185.

https://doi.org/10.1016/j.idairyj.2005.01.011

Haug, A., Høstmark, A.T., Harstad, O.M., (2007). Bovine milk in human nutrition-a review. Lipids in health and disease, 6(1), 25.

https://doi.org/10.1186/1476-511X-6-25

İnci, A., Aypak, S.Ü., Güven, G. (2017). Aydın ilinde üretilen inek sütlerinde bazı ağır metal düzeylerinin araştırılmas1. Glda, 42(3).

https://doi.org/10.15237/gida.GD16079

İstanbulluoğlu, H., Oğur, R., Tekbaş, Ö.F., Bakır, B. (2013). Süt ve süt ürünlerinde ağır metal kirliliği. Türkiye Klinikleri Tip Bilimleri Dergisi, 33(2), 410-419.

https://doi.org/10.5336/medsci.2012-29718

İşleyici, Ö., Sancak, Y.C, Tuncay, R.M., Yücel, U.M. (2017). Determination of mineral substance and heavy metal levels in divle tulum cheese. Van Veterinary Journal, 28(3), 151-156.

Kahvecioğlu, Ö., Kartal, G., Güven, A., Timur, S. (2009). Metallerin çevresel etkileri-1. Metalurji Dergisi, 136, 47-53.

Kılıçel, F., Tarakçı, Z., Sancak, H., Durmaz. H. (2004). Otlu lorların mineral madde ve ağır metal içerikleri. Yüzüncü Yll Üniversitesi Tarım Bilimleri Dergisi, 14(1), 41-45.

Kirdar, S.S., Köse, Ş, Gün, İ., Ocak, E., Kurşun, Ö. (2015). Do consumption of Kargi tulum cheese meet daily requirements for minerals and trace elements? Mljekarstvo/Dairy, 65(3), 203-209.

https://doi.org/10.15567/mljekarstvo.2015.0307

Leonard, A., Gerber, G.B. (1997). Mutagenicity, carcinogenicity and teratogenicity of thallium compounds. Mutation Research, 387, 47-53.

https://doi.org/10.1016/S1383-5742(97)00022-7

Licata, P., Trombetta, D., Cristanı, M., Giofre, F., Martıno, D., Calo, M., Naccarı, F. (2004). Levels of "toxic" and "essential" metals in samples of bovine milk from various dairy farms in Calabria, Italy. Environment International, 30(1), 1-6.

https://doi.org/10.1016/S0160-4120(03)00139-9

Mendil, D. (2006). Mineral and trace metal levels in some cheese collected from Turkey. Food Chemistry, 96(4), 532537.

https://doi.org/10.1016/j.foodchem.2005.03.006

Öksüztepe, G., Karatepe, P., Özçelik, M., İncili, G. K. (2013). Tulum peyniri ve taze beyaz peynirlerin mineral madde ve ağır metal içerikleri. Fırat Üniversitesi Sağlık Bilimleri Veteriner Dergisi, 27(2), 93-97.

Özbek, N., Akman, S. (2016). Microwave plasma atomic emission spectrometric determination of $\mathrm{Ca}, \mathrm{K}$ and $\mathrm{Mg}$ in various cheese varieties. Food Chemistry, 192(1), 295-298. https://doi.org/10.1016/j.foodchem.2015.07.011

Özlü, H., Atasever, M., Urçar, S., Atasever, M. (2012). Erzurum'da tüketime sunulan kaşar peynirlerinin mineral madde içeriği ve ağır metal kontaminasyonu. Kafkas Universitesi Veteriner Fakültesi Dergisi, 18(2), 205-208.

https://doi.org/10.9775/kvfd.2011.5258 
Özturan, K., Atasever, M., (2018). Süt ve ürünlerinde mineral maddeler ve ağır metaller. Atatürk Üniversitesi Veteriner Bilimleri Dergisi, 13(2), 229-241.

https://doi.org/10.17094/ataunivbd.317822

Öztürk, B.E. (2009). “Trakya bölgesinde satılan kaşar peynirlerinde ağır metal aranması", Yüksek lisans tezi, Tez Danışmanı: Şimşek, O., Namık Kemal Üniversitesi.

Paksoy, N., Dinç, H., Altun, S.K. (2018). Evaluation of levels of essential elements and heavy metals in milks of dairy donkeys, goats and sheep in Turkey. Pakistan Journal of Zoology, 50(3).

https://doi.org/10.17582/journal.pjz/2018.50.3.1097.1105

Park, Y.W. (2000). Comparison of mineral and cholesterol composition of different commercial goat milk products manufactured in USA. Small Rumin Research, 37(1-2), 115-124. https://doi.org/10.1016/S0921-4488(99)00144-3

Serencam, H., Arslaner, A., Köse, M. (2018). Civil peynirde ağır metal kontaminasyon kaynağ 1 ve düzeyinin belirlenmesi üzerine bir araştırma. Engineering Sciences, 13(1), 21-26.

https://doi.org/10.12739/NWSA.2018.13.1.1A0397
Şanal, H., Güler, Z. (2010). Changes in non-essential element concentrations during torba yoghurt production. Akademik Glda, 8(4), 6-12.

Şimşek, O., Gültekin, R., Öksüz, O., Kurultay, Ş. (2000). The effect of environmental pollution on the heavy metal content of raw milk. Nahrung, 44, 360-363.

https://doi.org/10.1002/1521-

3803(20001001)44:5<360::AID-FOOD360>3.0.CO;2-G

Temurci, H., Güner, A. (2006). Ankara'da tüketime sunulan süt ve beyaz peynirlerde ağır metal kontaminasyonu. Atatürk Üniversitesi Veteriner Bilimleri Dergisi, 1(2), 20-28.

Yalçın, Ö., Tekinşen, K.K. (2010). Konya'da tüketime sunulan beyaz salamura, tulum ve kaşar peynirlerinin ağır metal içeriklerinin araştırılması. Etlik Veteriner Mikrobiyolji Dergisi, 21(1), 5-10.

Yüzbaşı, N., Sezgin, E., Yıldırım, Z., Yıldırım, M. (2009). Changes in lead, cadmium, iron, copper and zinc levels during the production of Kaşar cheese. Journal of Food Quality, $32,73-83$.

https://doi.org/10.1111/j.1745-4557.2007.00167.x 